\title{
FRAGMENT SIZE OF CORN SILAGE ACCORDING TO THE DRY MATTER AND FORAGE HARVESTER ADJUSTMENTS
}

\section{PEDRO H. WEIRICH NETO ${ }^{1}$, PAULO W. GARBUIO ${ }^{2}$, NÁTALI M. DE SOUZA ${ }^{2}$, HEVANDRO C. DELALIBERA ${ }^{2}$, KHETLEN LEITÃO ${ }^{2}$}

\begin{abstract}
In Brazil, the best results in milk production are found in the state of Paraná. Such results are reached through genetic selection of the animals and management of their diets, in which whole plant corn silage is widely used. Aiming the silage quality, it was evaluated the influence of dry matter content of the corn culture as forage and the harvester adjustments on the fragment size of whole plant corn silage. The fragment size of two corn hybrids silage (SPEED and 2B688) was evaluated using a $5 \times 3$ factorial, with 4 repetitions. The first factor was the harvest time of the plants (105, 108, 112, 118, and 123 days after sowing (DAS)), which determines the forage dry matter (DM) content. The second factor was the harvester adjustments $(2,6.5$ and $11 \mathrm{~mm}$ of theoretical fragment length (TFL)). The DM content did not affect the average fragment size of 2B688. For SPEED, however, the real fragment size decreased as the maturation of plants increased. The conclusion is that the DM content and harvester adjustments can affect the real fragment sizes, according to different plant genotypes. The alterations of the harvester adjustments resulted in different fragment sizes, however, it were different from those indicated by the manufacturer.
\end{abstract}

KEYWORDS: ensilage, whole plant silage, harvest time.

\section{TAMANHO DE FRAGMENTO DE SILAGEM DE MILHO CONFORME MATÉRIA SECA E REGULAGENS DE UMA COLHEDORA DE FORRAGEM}

RESUMO: No Brasil, os melhores índices em produtividade leiteira encontram-se no Paraná. Tais índices são alcançados devido à seleção genética dos animais e ao manejo alimentar, onde a silagem de planta inteira de milho tem sido largamente utilizada. Objetivando qualidade de silagem, avaliaram-se a influência do teor de matéria seca da cultura do milho como forragem e das regulagens da colhedora sobre o tamanho de fragmento de silagem de planta inteira de milho. Num fatorial $5 \times 3$, com quatro repetições, analisou-se o tamanho de fragmento da silagem de dois híbridos de milho (SPEED e 2B688). O primeiro fator foram as épocas de colheita (105; 108; 112, 118 e 123 dias após a semeadura (DAS)), as quais determinam os teores de matéria seca (MS) da forragem. $\mathrm{O}$ segundo fator consistiu nas regulagens da máquina (2; 6,5 e $11 \mathrm{~mm}$ de comprimento teórico de fragmento (CTF)). Para o híbrido 2B688, os teores de MS não mostraram efeito sobre o tamanho médio de fragmento. Porém, para o híbrido SPEED, verificou-se redução no tamanho de fragmento real com a maturação das plantas. Concluiu-se que os teores de MS, bem como as regulagens da máquina podem interferir nos tamanhos de fragmentos reais, de acordo com o genótipo. As alterações das regulagens da colhedora resultaram em tamanhos diferentes de fragmento, porém não correspondentes àqueles indicados pelo fabricante.

PALAVRAS-CHAVE: ensilagem, silagem de planta inteira, época de colheita.

\footnotetext{
${ }^{1}$ Universidade Estadual de Ponta Grossa (UEPG), Departamento de Ciência do Solo e Engenharia Agrícola, Laboratório de Mecanização Agrícola (Lama).

${ }^{2}$ Universidade Estadual de Ponta Grossa (UEPG), Departamento de Ciência do Solo e Engenharia Agrícola, Laboratório de Mecanização Agrícola (Lama), Programa de Pós-Graduação em Agronomia, Bolsista CAPES/DS. 


\section{INTRODUCTION}

One of the problems with the feeding of ruminants in Brazil is the seasonality of forage production throughout the year (SANTOS et al., 2009). In this context, the use of whole plant silage corn appears as an alternative, because as well as major forage production and composition of the plant in terms of energy and fiber, it results in adequate fermentation in the silo and the resulting high quality silage (VON PINHO et al., 2007).

Corn silage provides 50-100\% more digestible energy per acre than any other forage (VELHO et al., 2007). However, its quality is related to some variables of ensilage process, as the choice of the genotype, the water content of the material, the size of the fragment, the degree of compaction and type of silo (NEUMANN et al., 2007a). For ZOPOLLATTO et al. (2009), in addition to the inherent characteristics of the corn plant, environmental cultivation issues such as climate conditions, cultivation treatment, sowing density and harvesting time should be considered.

As an indicative for the beginning of the ensilage process, is the dry matter content (DM) of the plant, which according to BAL et al. (2000) should be between 30 and 35\%. Harvests either before or after this age considered ideal, cause reduced quality of silage.

After choose the moment of harvest, the fragmentation of the plants is carried out by a forage harvester, of which ability to cut plant material depends on intrinsic and extrinsic factors. Intrinsic factors are related to the harvester itself, i.e., its structural dimensions, cutting devices, the adjustments, among others. The extrinsic factors are related to operating conditions such as the amount of mass to be cut, feed rate and the material to be cut (plant age, plant species, and others) (PRASAD \& GUPTA, 1975). SRIVASTAVA et al. (2006) point out that living plants are made of solid material with the presence of liquids and air in its interstices, and the composition of its fibers, which are the main structures that offer, cut resistance.

The fragment size provided by a forage harvester can be reduced by increasing the tangential velocity of the cutting blades. However, factors amenable to human action as the sharpening, the angular spacing between the cutting rotor blades and the distance between the rotor blades and static blade, are also able to influence the size of the fragment (SRIVASTAVA et al ., 2006).

The fragment size has been reported as extremely important for the consumption of forage by the animal (BAL \& BAL, 2010; CAO et al., 2010; HARA \& TANIGAWA, 2010; CONE et al., 2008; NEUMANN et al., 2007b; NEUMANN et al., 2007c), and the higher the DM content, the smaller the particle size should be. For the corn whole plant silage, the fragments should be from 12 to $16 \mathrm{~mm}$ of DM content lower than 28\%, from 8 to $12 \mathrm{~mm}$ if the DM is between 30 and $37 \%$ and from 5 to $8 \mathrm{~mm}$ with DM above 37\% (FERREIRA, 2001).

The aim of this study was to evaluate the influence of the dry matter content of the forage and the harvester adjustments on the fragment size of whole plant silage of two corn genotypes.

\section{MATERIAL AND METHODS}

The study was conducted at the School Farm of the Center for Education of Campos Gerais CESCAGE with approximate latitude and longitude of $25^{\circ} 10^{\prime} 37,19^{\prime \prime}$ S and $50^{\circ} 06^{\prime} 50,66^{\prime \prime}$ 'W, and an average altitude of $969 \mathrm{~m}$. The climate, according to Köppen is classified as Cfb or temperate, with frequent frosts in the winter, cool summers and no defined dry season (CAVIGLIONE et al., 2000).

The corn hybrids used were $2 \mathrm{~B} 688^{\circledR}$ and SPEED ${ }^{\circledR}$. The first is a triple hybrid of early cycle, recommended for use as grain or whole plant silage. The second is a simple hybrid of early cycle recommended for use as grain. Both were grown in the area of occurrence of typical dystroferric red latosol, clayey texture (BRAZILIAN COMPANY OF AGRICULTURAL RESEARCH /EMBRAPA, 2009). Using precision seed planter set to obtain 60,000 plants ha ${ }^{-1}$ with row spacing 
of $0.85 \mathrm{~m}$, approximately 4 ha were sown for each genotype in November 17, 2006. The fertilization at sowing was the incorporation of $430 \mathrm{~kg} \mathrm{ha}^{-1}$ of the formula $08-28-16$ (NPK) and as coverage fertilization in the second half of December was applied $100 \mathrm{~kg} \mathrm{ha}^{-1}$ of urea, containing $450 \mathrm{~g} \mathrm{~kg}^{-1}$ of nitrogen. As cultivation treatments, was applied $3 \mathrm{~L} \mathrm{ha}^{-1}$ of Primóleo ${ }^{\circledR}\left(400 \mathrm{~g} \mathrm{~L}^{-1}\right.$ of atrazine) and $0.2 \mathrm{~L}$ of Callisto ${ }^{\circledR}$ (480 $\mathrm{g} \mathrm{L}^{-1}$ of mesotrione) for weed control, and $0.15 \mathrm{~L} \mathrm{ha}^{-1}$ of Karate $^{\circledR}$ (50 g L ${ }^{-1}$ of lambda-cyhalothrin) for insect control.

The test area consisted of five rows of plants with a length of $50 \mathrm{~m}$ for each hybrid. For the characterization of the varieties used and the experimental area at flowering stage was evaluated the plant height, stem diameter, plant spacing, using for both a self -made ruler with an accuracy of 1 $\mathrm{cm}$, caliper (Mitotoyo) with an accuracy of $0.1 \mathrm{~mm}$ and commercial tape with accuracy of $1 \mathrm{~mm}$, respectively. These procedures were performed in the area composed by four rows of $4 \mathrm{~m}$ of plants. With the spacing between plants, it was calculated the plant population, which was obtained by multiplying the sum of the two halves of the spacing between rows, and the sum of half the spacing of plants in the rows, thereby obtaining the individual area theoretically occupied by each plant. This measure was extrapolated to the number of plants per one hectare. For all variables described above, it was preceded the normality analysis, the Kolmogorov-Smirnov test, with subsequent descriptive analysis.

The experimental design was completely randomized, in a $5 \times 3$ factorial arrangement with four replications. The first factor consisted of the harvest time, which determines the DM content of the forage and the second factor were the adjustments of the harvester, which determine the theoretical fragment length (TFL). Each hybrid used was considered a separate experiment.

The material harvest times were 105, 108, 112, 118, and 123 days after sowing (DAS). In each time, 130 plants of each hybrid at $0.10 \mathrm{~m}$ above the ground were cut manually. It was used five of these plants (replicates) for the determination of their green and dry mass (DM for manual processing), while for the determination of green and dry mass of silage (DM by moto mechanized processing) was used volume of $1 \mathrm{~L}$ with six replications. After measuring the green mass of these materials, they were subjected to forced air oven at $60^{\circ} \mathrm{C}$ for $72 \mathrm{~h}$ or until the mass was stabilized. The results were used to calculate the yield in $\mathrm{kg} \mathrm{ha}^{-1}$

For the fragmentation of the plants was used a JF $90 \mathrm{Z} 10^{\circledR}$ forage harvester, which has adjustments for obtaining theoretical fragment length (TFL) ranging from 2 to $22 \mathrm{~mm}$. The TFL adjustments used were 2, 6.5 and $11 \mathrm{~mm}$. It was chosen to work with the harvester parked, and then the samples were formed by ten corn plants with four replications (40 plants) for each of the three treatments, placed two by two on the harvester. The cutting rotor blades were sharpened through manual operation for five minutes prior to fragmentation of plants that formed each treatment. The forage harvester was driven by a tractor; observing the rotation in the power take-off to be maintained constant at $540 \mathrm{~min}^{-1}$. From the fragmented material in each repetition, we withdrew a sample of approximately $8 \mathrm{~L}$ for fragment size determination.

The samples were carried out to the laboratory and submitted to the methodology adapted from the standard ASAE S424 (1995). Each sample of $4 \mathrm{~L}$ of silage was placed on the set of sieves and segregated by agitation (60 s) and gravity action. After this time, it was determined the mass retained on each sieve into digital scale with an accuracy of $0.1 \mathrm{~g}$. In determining the average fragment size, was used the weighted average of the mass retained on each sieve.

The obtained values were subjected to analysis of variance and posterior averages test or regression analysis. To compare the means, it was used the Tukey test at $5 \%$ probability. The analyses were performed using Microsoft Excel and Assistat 7.5.

\section{RESULTS AND DISCUSSION}

According to meteorological data obtained from the weather station of the Agronomic Institute of Paraná (IAPAR), located approximately $4 \mathrm{~km}$ from the experiment, it can affirm that the 
minimum and maximum temperatures and the rainfall during the cycle were normal, near the regional historical series.

The values of coefficients of variation (CVs \%) obtained for plant height and stem diameter were 4.5 and $17.2 \%$ for hybrids SPEED and 2B688, respectively. To plant spacing, the CVs were 99.8 and 52.0\%, while the population pressure values were 97 and 32\% for the same hybrids. These values are higher than those found by SCHIMANDEIRO et al. (2006) for the region, having been caused by possible inefficiency in the process of seeding genotypes. However, we can affirm that the high CVs did not affect the assessments made in the study, because the harvester operated parked with constant processing plants rate by manual supplying, which remained constant the vegetal volume processed per unit of time.

The means of plant populations of 52,160 plants ha ${ }^{-1}$ for the 2B688 Hybrid and 55,695 plants $\mathrm{ha}^{-1}$ for the SPEED hybrid show that it did not reach the recommended of 60 thousand plants ha ${ }^{-1}$. In general, there was great variability in plant populations and low in plant phytotechnical characteristics. The great variability in plant populations could influence feeding rate and consequently the effort of fragmentation (PRASAD \& GUPTA, 1975); however, is not the case of this study, because the plants were manually cut and the machine supply (static) was given steadily.

Regarding the content of DM, either by manual or moto mechanized processing (Figure 1), there were differences regarding the extreme dates of harvest. In the 18-day interval, the amplitude of silage DM content was $12.5 \%$ for the SPEED hybrid, while for the 2B688 Hybrid was 12.1\%. ZEOULA et al. (2003) in similar climatic conditions identified for five hybrids, in the interval of 18 days, the mean amplitude of $12.07 \%$ in DM content.

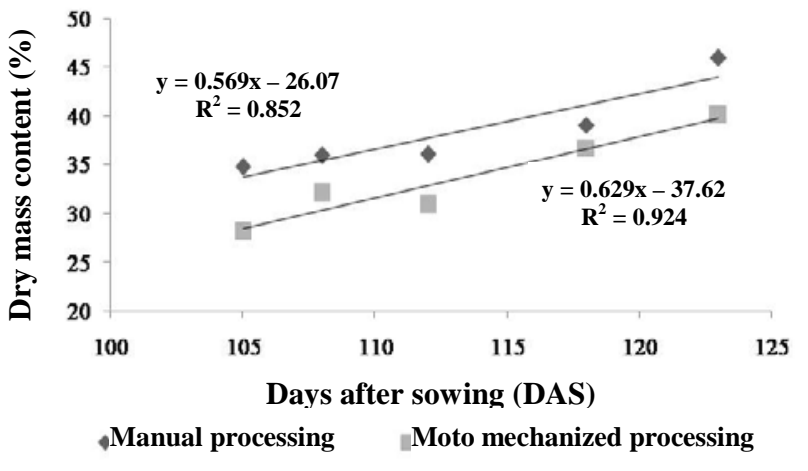

2B688 Hybrid

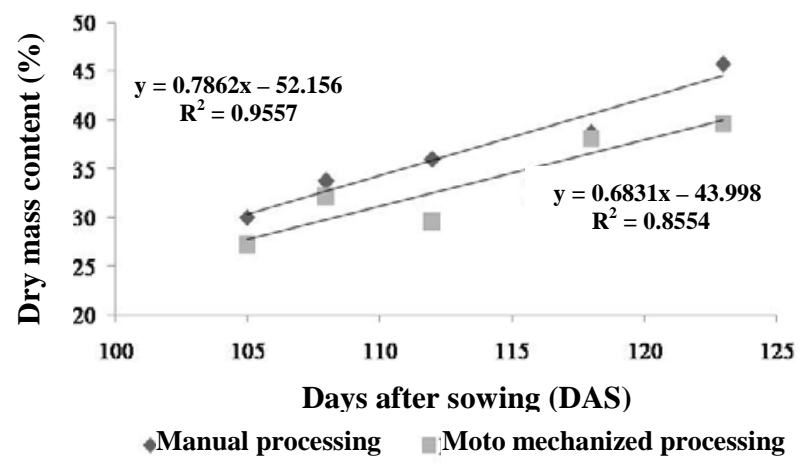

SPEED hybrid

FIGURE 1. Means of DM content of corn plants with manual and moto mechanized (forage harvester) processing of the 2B688 and SPEED hybrids, according to the harvest times.

In the four-day interval between harvests, it was found that the DM for the two types of processing were similar between the second (108 DAS) and third cutting period (112 DAS) for both hybrids. This may be due to the cumulative rainfall of $42 \mathrm{~mm}$ between the two dates, which may have led the culture to accumulate nonstructural water. In the mean of the harvest period, for both genotypes, was found that the DM content by manual processing was superior to moto mechanized DM. This fact shows that, depending on the methodology that is adopted for the determination of dry matter, there may be differences in the obtained results.

Figure 2 shows the yields of total green mass, total dry mass and total dry mass of grains in cut times, considering the moto mechanized DM. No differences were observed for total dry mass yield between harvest times for the two materials. 


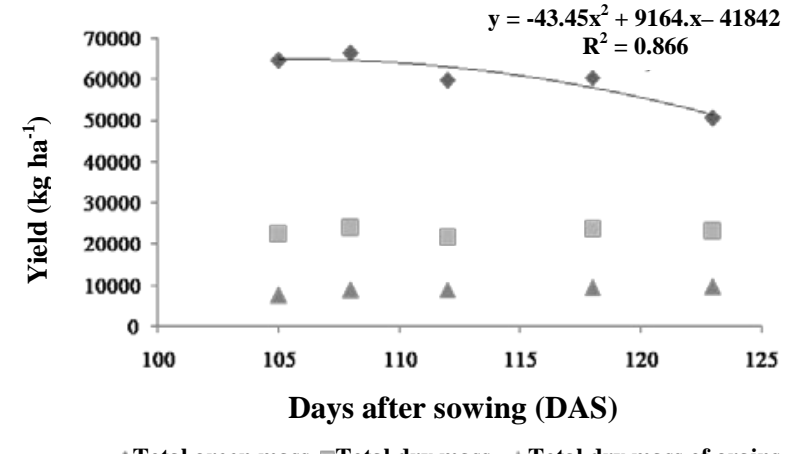

2B688 Hybrid

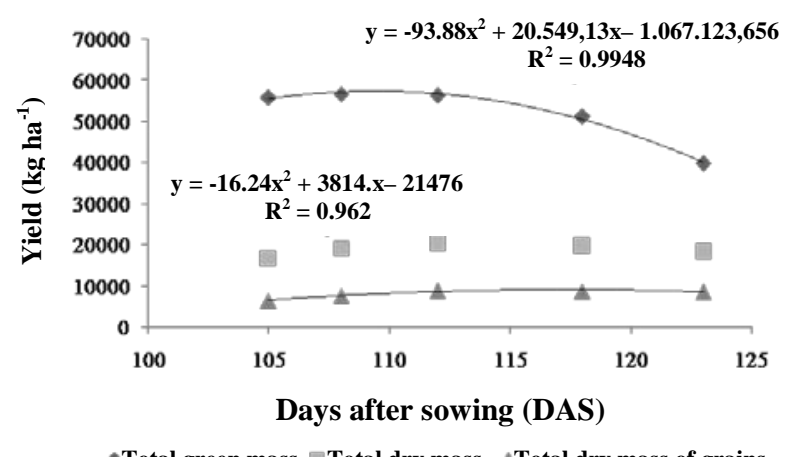

- Total green mass $₫$ Total dry mass $\Delta$ Total dry mass of grains

SPEED hybrid

FIGURE 2. Total green mass, total dry mass and total dry mass of grain yield of the $2 \mathrm{~B} 688$ and SPEED hybrids, according to the harvest times.

For the SPEED hybrid, it was found difference to the yield of grains, represented by dry mass of grains, between the harvests (Figure 2). However, we found equal from the second to the fifth harvest time, which considering the yields of total dry matter and of grains, the harvest could be started from the content of 36.02\% DM (108 DAS). For the 2B688 Hybrid no differences were found for yield of grains.

Among the harvest times for 2B688 Hybrid (Figure 3) there was no difference in the average size of the fragment, with an average of $7.06 \mathrm{~mm}$. With extremes of water content of 58 and $0 \%$, KONONOFF et al. (2003) found differences for the average size of fragment. There was statistical difference for 2B688 Hybrid only among average sizes of fragments for the factor adjustment.

Regarding the SPEED hybrid, we identified interaction between the adjustments and harvest times factors. Similarly to KONONOFF et al. (2003), we found, for the adjustments of larger fragments, the reduction of the average size of fragment with increase of DM content (Figure 3). This shows that the adjustments to be used depends on the time in which it is harvesting the forage, i.e., the mass content, information that can be recommended to producers and also the manufacturers of agricultural machinery, both at the time of regulate the harvesters and in the writing of operation manuals.

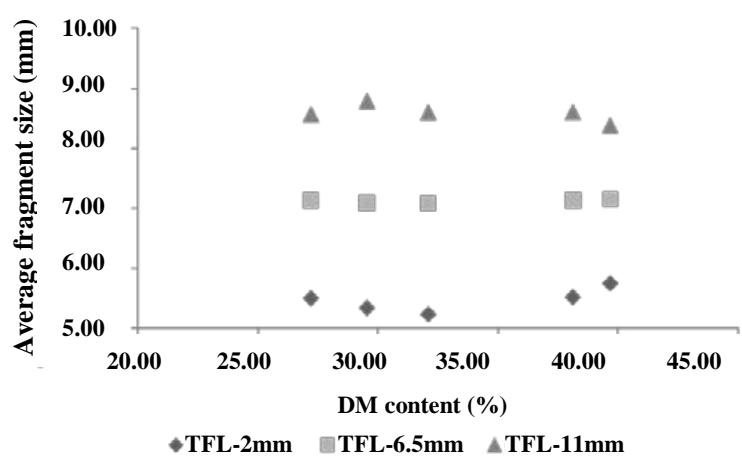

2B688 Hybrid

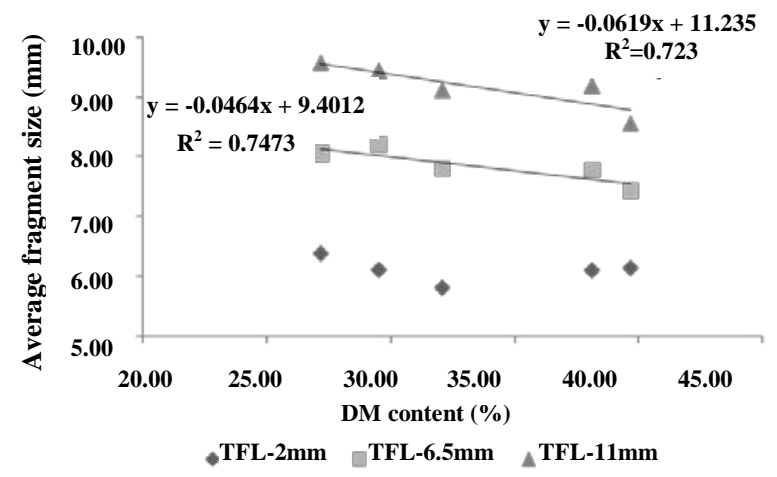

SPEED hybrid

FIGURE 3. Fragment size means (mm) of whole plant silage of 2B688 and SPEED hybrids at 5 harvest times.

The differences in the adjustments of 6.5 and $11 \mathrm{~mm}$ of TFL can be partially explained by the higher percentage of grains with the increase in DM content of silage (Figure 4). As the most representative fraction, the grains pass through a sieve of $12.7 \mathrm{~mm}$ diameter and are deposited on the inferior sieves ( $6 \mathrm{~mm}, 4 \mathrm{~mm}$ and deep). This can change the final result indicating fragment size reduction by increasing the concentration of the retained material in these sieves. In the case of adjustment of $2 \mathrm{~mm}$ of TFL, the above hypothesis can not be considered, since in this case the 
fragmentation is increased in relation to previous adjustments. The forage harvester, when properly regulated (sharpening knives, gear ratio, correct feed rate), can perform the fragmentation of plants, even with high levels of DM.
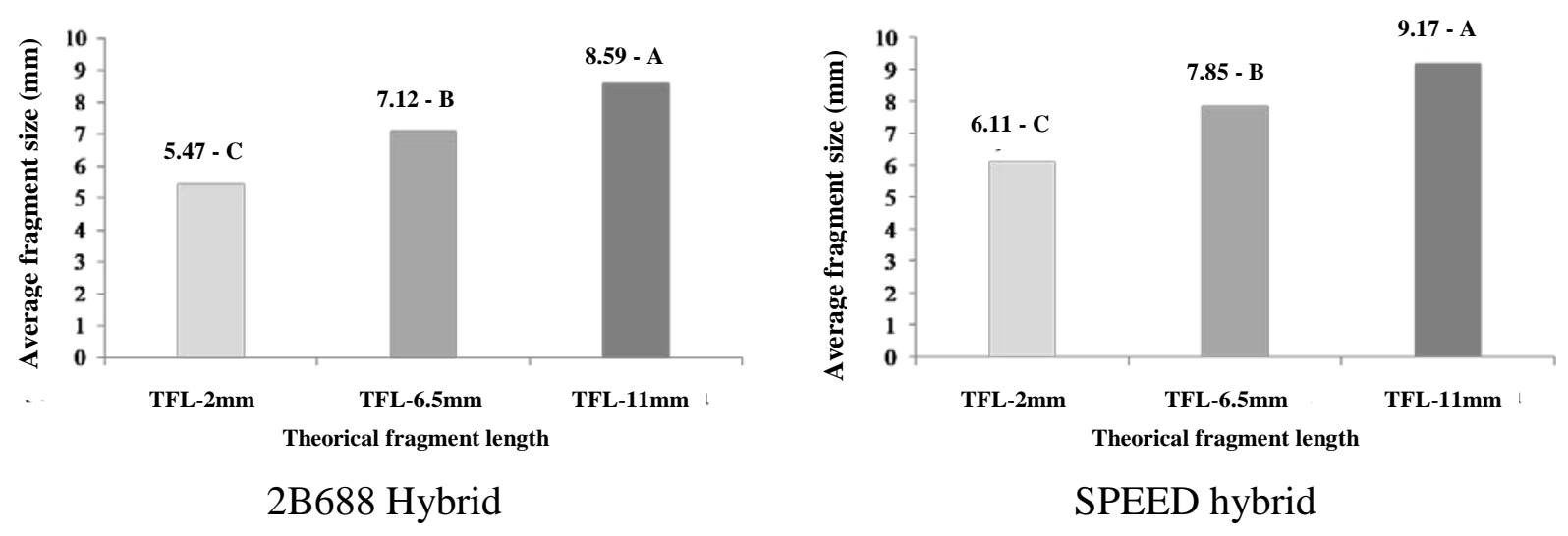

FIGURE 4. Means of fragment size (mm) of whole plant silage of 2B688 and SPEED hybrids at different adjustments of the forage harvest.

It is noteworthy that the theoretical fragment length (TFL) described in the manual of the forage harvester, does not match the actual average size of the fragment (Figure 4). In a recent study, SCHLOSSER et al. (2010) reported a little satisfactory work of the forage harvester, which was demonstrated by the wide range in sizes of fragments resulting from processing sorghum and corn cultures.

\section{CONCLUSIONS}

For the SPEED hybrid, there was an increase in grain yield (dry mass of grains) with increasing DM (conforming the harvest time), and reduction of the size of the fragment.

In the 2B688 Hybrid there was no variation in yield of total dry matter and of grains and in the size of the fragments conforms the harvest time.

The alterations of the adjustments of the harvester resulted in different fragment sizes, however not corresponding to those specified by the manufacturer.

\section{REFERENCES}

AMERICAN SOCIETY OF AGRICULTURE ENGINEERS. Method of determining and expressing particle size of chopped forage. ANSI/ASAE S424. St. Joseph: ASAE Standards, 1995. p. 459-461.

BAL, M.A.; SHAVER, R.D.; AL-JOBEILE, A.; COORS, J.G.; LAUER, J.G. Corn Silage Hybrid Effects on Intake, Digestion, and Milk Production by Dairy Cows. Journal of Dairy Science, Champaign, v.83, n.12, p.2849-2858, 2000.

BAL, M.A.; BAL, E.B.B. Interaction between particle sizes of alfalfa hay and corn grain on milk yield, milk composition, chewing activity, and ruminal $\mathrm{pH}$ of dairy cows. Turkish Journal of Veterinary and Animal Sciences, Yahsihan, v.34, n.1, p.83-89, 2010.

CAO, Z.; MA, M.; JI, P.; LI, S. Effects of maize silage particle size and feeding method on ruminal fermentation, chewing activity and passage rate of lactation cows. Journal of Animal and Veterinary Advances, New York, v.9, n. 2, p.374-383, 2010.

CAVIGLIONE, J. H.; KIIHL, L. R. B.; CARAMORI, P. H.; OLIVEIRA, D. Cartas climáticas do Paraná. Londrina: IAPAR, 2000. CD-ROM. 
CONE, J.W.; VAN GELDER, A.H.; VAN SCHOOTEN, H.A.; GROTEN, J.A.M. Effects of chop length and ensiling period of forage maize on in vitro rumen fermentation characteristics. NJAS Wageningen Journal of Life Sciences, Wageningen, v.55, n.2, p.155-166, 2008.

EMPRESA BRASILEIRA DE PESQUISA AGROPECUÁRIA/EMBRAPA. Centro Nacional de Pesquisa de Solos. Sistema brasileiro de classificação de solos. Rio de Janeiro: EMBRAPA-SPI, 2009. 412p.

FERREIRA, J. J. Efeito do processamento da planta de milho na qualidade da silagem. In: CRUZ, J. C. et al. Produção e utilização de silagem de milho e sorgo. Sete Lagoas: Embrapa Milho e Sorgo, 2001. cap. 18, p.445-472.

HARA, S.; TANIGAWA, T. Effects of length of cut and mechanical processing on utilization of corn silage harvested at the black line stage of maturity by lactating dairy cows. Animal Science Journal, Tokyo, v. 81, p.187-193, 2010.

KONONOFF, P. J.; HEINRICHS, A.J.; BUCKMASTER, D.R. Modification of the Penn State Forage and Total Mixed Ration Particle Separator and the Effects of Moisture Content on its Measurements. Journal of Dairy Science, Champaign, v.86, n.5, p.1853-1863, 2003.

NEUMANN, M.; MÜHLBACH, P.R.F.; NÖRNBERG, J.L.; OST, P.R.; RESTLE, J.; SANDINI, I.E.; ROMANO, M.A. Características da fermentação da silagem obtida em diferentes tipos de silos sob efeito do tamanho de partícula e da altura de colheita das plantas de milho. Ciência Rural, Santa Maria, v.37, n.3, p.847-854, mai-jun., 2007a.

NEUMANN, M.; MÜHLBACH, P.R.F.; NÖRNBERG, J.L.; RESTLE, J.; OST, P.R. Efeito do tamanho de partícula e da altura de colheita de plantas de milho (Zea mays L.) para ensilagem na produção do novilho superprecoce. Revista Brasileira de Zootecnia, Viçosa-MG, v.36, n.5, p.16141623, 2007b (supl.).

NEUMANN, M.; MÜHLBACH, P.R.F.; NÖRNBERG, J.L.; RESTLE, J.; OST, P.R.; LUSTOSA, S.B.C. Efeito do tamanho de partícula e da altura de corte de plantas de milho na dinâmica do processo fermentativo da silagem e no período de desensilagem. Revista Brasileira de Zootecnia, Viçosa-MG, v.36, n.5, p.1603-1613, 2007c. Suplemento.

PRASAD, J.; GUPTA, C. P. Mechanical properties of maize stalk as related to harvesting. Journal of Agriculture Engineering Research, London, v.20, n.1, p.79-87, 1975.

SANTOS, G.T.; MODESTO, E.C.; SOUZA, N.E.; ÍTAVO, L.C.V.; JOBIM, C.C.; SILVAKAZAMA, D.C.; VALLOTO, A. A.; MASSUDA, E. M. Replacement of corn silage wiht cassava foliage silage in the diet of lactating dairy cows: Milk composition and economic evaluation. Brazilian Archives of Biology and Technology, v.52, Curitiba, p.259-267, 2009. Número especial.

SCHIMANDEIRO, A.; WEIRICH NETO, P.H.; GIMENEZ, L.M.; COLET, M.J.; GARBUIO, P.W. Distribuição longitudinal de plantas de milho (Zea mays L.) na região dos Campos Gerais, Paraná. Ciência Rural, Santa Maria, v.36, n.3, p.977-980, 2006.

SCHLOSSER, J.F.; DORNELLES, M.E.; PINHEIRO, E.D.; DURIGON, R.; RUSSINI, A. Uniformidade de picado processado por colhedora de forragem. Engenharia Agrícola, Jaboticabal, v.30, n.2, p.299-306, 2010.

SRIVASTAVA, A.K.; GOERING, C.E.; ROHRBACH, R.P.; BUCKMASTER, D.R. Hay and Forage Harvesting. In: ASAE. Engineering Principles of Agricultural Machines. St. Joseph: ASAE, 2006. cap. 11, p. 325-402.

VELHO, J.P.; MÜHLBACH, P.R.F; NÖRNBERG, J.L.; VELHO, I.M.P.H.; GENRO, T.C.M.; KESSLER, J.D. Composição bromatológica de silagens de milho produzidas com diferentes densidades de compactação. Revista Brasileira de Zootecnia, Viçosa-MG, v.36, n.5, p.1532-1538, 2007. 
VON PINHO, R.G.; VASCONCELOS, R.C.; BORGES, I.D.; RESENDE, A.V. Produtividade e qualidade da silagem de milho e sorgo em função da época de semeadura. Bragantia, Campinas, v.66, n.2, p.235-245, 2007.

ZEOULA, L.M.; BELEZE, J.R.F.; CECATO, U.; JOBIM, C.C.; GERON, L.J.V.; PRADO, O.P.P.; FALCÃO, A.J.S. Avaliação de Cinco Híbridos de Milho (Zea mays L.) em Diferentes Estádios de Maturação. 4. Digestibilidade da Matéria Seca, Matéria Orgânica e Fibra em Detergente Neutro da Porção Vegetativa e Planta Inteira. Revista Brasileira de Zootecnia, Viçosa-MG, v.32, n.3, p. 567575, 2003.

ZOPOLLATTO, M.; NUSSIO, L.G.; PAZIANI, S.F.; RIBEIRO, J.L.; SARTURI, J.O.; MOURÃO, G.B. Relações biométricas entre o estádio de maturação e a produtividade de híbridos de milho para produção de silagem. Revista Brasileira de Zootecnia, Viçosa-MG, v.38, n.2, p.256-264, 2009. 